\title{
SPRAWIEDLIWOŚĆ I ODPOWIEDZIALNOŚĆ W EDUKACJI GLOBALNEJ (W NARRACJACH PRZEDSTAWICIELI ORGANIZACJI POZARZĄDOWYCH) ${ }^{\star}$
}

Streszczenie: Celem artykułu jest analiza kategorii sprawiedliwości i odpowiedzialności w narracjach osób z sektora pozarządowego zajmujących się edukacją globalną w Polsce. Obie kategorie traktowane są w tekście jako konstrukty społeczno-kulturowe, będące zarówno rezultatem praktyki społecznej, jak i przyczyniające się do jej przekształcania. Zastosowana metoda badawcza to jakościowa analiza treści 12 indywidualnych wywiadów pogłębionych, uzupełniona o analizę konkordancji. Ramę teoretyczną analizy stanowiła krytyczna edukacja globalna i podejście dyskursywne. Analiza umożliwiła odsłonięcie dominujących reprezentacji sprawiedliwości i odpowiedzialności oraz ich potencjalnych konsekwencji. Odpowiedzialność w wywiadach wiąże się z wolnym wyborem, autonomią jednostki i realną możliwością wpływania na świat. Przypisywana jest mieszkankom i mieszkańcom globalnej Północy. Jest to odpowiedzialność za, a nie wobec Innego, który jest jedynie obiektem działań. Dominujące reprezentacje sprawiedliwości i niesprawiedliwości także konstytuują ludzi z globalnej Północy jako niewinne podmioty działania, od których zależą losy globalnego Południa. Alternatywne reprezentacje wybrzmiewają znacznie słabiej.

Słowa kluczowe: edukacja globalna, dyskurs, organizacje pozarządowe, sprawiedliwość, odpowiedzialność, metody jakościowe.

* Artykuł powstał w ramach projektu badawczego realizowanego w latach 2013-2015, finansowanego ze środków Wydziału Pedagogicznego Uniwersytetu Warszawskiego na działalność statutową (BST 16/17080o/2014). Chciałabym serdecznie podziękować wszystkim osobom, które zgodziły się wziąć udział w badaniach, za okazane mi zaufanie i poświęcony czas. Dziękuję także Monice Gromadzkiej i Marcie Wiatr za komentarze do pierwszej wersji tekstu. Choć nie wszystkie uwzględniłam, to stały się one przyczynkiem do fascynujących dyskusji. 


\section{Wprowadzenie}

Sprawiedliwość i odpowiedzialność to kategorie niemal nieodłącznie związane z edukacją globalną, zarówno gdy jest mowa o literaturze akademickiej (Andreotti 2011; Bourn 2015; Ciążela 2012), działaniach i publikacjach organizacji pozarządowych (GLEN 2009; program „Edukacja globalna” realizowany przez Centrum Edukacji Obywatelskiej: http://globalna.ceo.org.pl), jak i dokumentach czy publikacjach międzynarodowych (UNESCO 2014). Zbyt często jednak przyjmuje się milczące założenie o ich oczywistości, o tym, że są „zrozumiałe same przez się", nie podejmując prób wniknięcia w sposób ich rozumienia, możliwe napięcia i sprzeczności bądź alternatywne interpretacje.

Zwrot dyskursywny w naukach społecznych i humanistycznych zakwestionował postrzeganie rzeczywistości jako obiektywnej i zwrócił uwagę badaczy oraz badaczek na komunikacyjne i językowe aspekty życia społeczno-kulturowego (Ostrowicka 2014). Zgodnie z podejściem dyskursywnym rzeczywistość jest konstruowana w społecznych procesach komunikacji, a język i sposób jego użycia nie są ani neutralne, ani transparentne. Dyskurs, rozumiany jako język w użyciu, jest konstruktem społeczno-kulturowym, nośnikiem określonych wizji świata, norm i wartości. Jednocześnie sam konstytuuje świat społeczny (Wodak, Fairclough 1997). Kategorie sprawiedliwości i odpowiedzialności pojawiające się w wypowiedziach ustnych i pisemnych mogą być traktowane jako konstrukty społeczno-kulturowe, wyrastające z pewnych ukrytych założeń, nadające rzeczywistości określone sensy i znaczenia. Analiza tych konstruktów, sposobów ich reprezentacji, tego, co obecne i nieobecne w wypowiedziach badanych, pozwala na odsłonięcie sposobów rozumienia rzeczywistości i potencjalnych skutków społeczno-kulturowo-edukacyjnych „pracy” dyskursu. Takich badań w obszarze edukacji globalnej w Polsce jest niewiele (zob. np. Popow 2015).

Celem artykułu jest częściowe wypełnienie tej luki dzięki analizie i rekonstrukcji kategorii sprawiedliwości i odpowiedzialności w narracjach osób z sektora pozarządowego zajmujących się edukacją globalną w Polsce. Chcę odpowiedzieć na pytanie, w jaki sposób te kategorie są dyskursywnie konstruowane przez osoby zajmujące się edukacją globalną w swej codziennej pracy - edukacyjnej, publikacyjnej czy organizacyjnej. W kontekście polskim to właśnie organizacje pozarządowe i pracujący w nich ludzie pełnią najbardziej znaczącą rolę w realizacji i rozwoju edukacji globalnej, dlatego też badania koncentrowały się na środowisku pozarządowym.

Podjęty problem badawczy jest istotny nie tylko z punktu widzenia zaspokojenia naukowej ciekawości, ale także w kontekście praktyki edukacyjnej. Niektóre dyskursy mogą bowiem utrwalać stereotypy, stygmatyzować i przyczyniać się do pogłębiania nierówności (Andreotti 2011; Jefferess 2008; Swanson, Pashby 2016). 


\section{Metoda}

Opisywane badania stanowią fragment szerszego projektu badawczego pt. „Edukacja globalna w Polsce - między zaangażowaniem a instytucjonalizacją" realizowanego w latach 2013-2015. W ramach projektu przeprowadziłam 12 indywidualnych wywiadów pogłębionych z pracownikami i pracownicami dziewięciu organizacji pozarządowych. Były to wywiady częściowo ustrukturyzowane. Dobór próby, jeśli chodzi o organizacje, był celowy - są to organizacje najprężniej działające w obszarze edukacji globalnej w Polsce. Wszystkie są zrzeszone w Grupie Zagranica, czyli stowarzyszeniu skupiającym polskie organizacje pozarządowe działające w sferze współpracy rozwojowej i edukacji globalnej. Wszystkie są beneficjentami konkursu Ministerstwa Spraw Zagranicznych „Edukacja Globalna” i od kilku lat realizują projekty z tego zakresu. Są to też organizacje prowadzące szkolenia dla mniejszych i początkujących organizacji. Moi rozmówcy i rozmówczynie to osoby z różnym doświadczeniem i pełniące różne role w tych organizacjach - były wśród nich osoby od kilkunastu lat zajmujące się edukacją globalną oraz takie, które miały doświadczenie roczne czy dwuletnie; byli koordynatorzy/koordynatorki programów edukacyjnych w organizacjach oraz trenerki pracujące bezpośrednio z uczniami i uczennicami; byli autorzy i autorki tekstów - analiz teoretycznych i publikacji edukacyjnych, w tym scenariuszy zajęć.

Wywiady zostały poddane transkrypcji, a następnie jakościowej analizie treści (por. Mayring 200o), w której wykorzystałam dwa rodzaje kodów. Były to kody teoretyczne, wyprowadzone z przyjętych koncepcji teoretycznych, i kody dosłowne (in $v i v o$ ), wyłaniające się $\mathrm{z}$ danych podczas procesu analizy. Analiza jakościowa została wsparta analizą konkordancji wykorzystywaną $\mathrm{w}$ analizie dyskursu, także $\mathrm{w}$ jej odmianie krytycznej (KAD). Analiza konkordancji jest techniką polegającą na poszukiwaniu w korpusie (w tym przypadku - w transkrypcjach wywiadów) wzorców wśród wszystkich wystąpień danego słowa, wraz z kontekstem, dzięki czemu można zidentyfikować dominujące dyskursy i dyskursywne reprezentacje analizowanych zjawisk (Kamasa 2014).

\section{Perspektywa teoretyczna}

Pisząc o koncepcjach teoretycznych, z których wywiedzione zostały kody, mam na myśli przede wszystkim perspektywę krytycznej, postkolonialnej edukacji globalnej (Andreotti 2006; 2011; Andreotti, de Souza 2014; Pashby 2014), która w znacznym stopniu ukształtowała moje rozumienie edukacji globalnej. Krytyczna edukacja globalna koncentruje się wokół takich kategorii, jak sprawiedliwość społeczna (zamiast dobroczynności), uznanie swego uwikłania w krzywdy i niesprawiedliwości, i wywodzące się z tego etyczne zaangażowanie w kwestie globalne. Celem jest przygotowanie ludzi do życia w zglobalizowanym i współzależnym świecie, 
tak aby potrafili kształtować ten świat i jego przyszłość, zamiast adaptować się do nich. Vanessa Andreotti promuje taką edukację globalną, która dąży do rozwijania kompetencji krytycznych (critical literacy), czyli umiejętności dostrzegania i krytycznego analizowania ukrytych założeń i implikacji różnych perspektyw czy punktów widzenia, także swojego własnego, po to, żeby otworzyć możliwości dla alternatywnych konceptualizacji, dla poszerzenia naszych perspektyw, poszerzenia horyzontów myślenia i współbycia $z$ Innym. To ma być proces transformatywnego uczenia się, które zmienia nie tylko podmiot uczący się, ale także społeczeństwo - w kierunku inkluzywnego, otwierającego się na nowe alternatywy czy głosy, zwłaszcza tych, którzy dotychczas nie byli słyszani (Andreotti 2014). Krytyczna edukacja globalna jest próbą stworzenia edukacji, która nie będzie hegemoniczna, etnocentryczna i paternalistyczna, edukacji bazującej na wzajemności i partnerstwie, promującej refleksyjność, krytyczne analizy relacji władzy i epistemologiczny pluralizm. Ta perspektywa teoretyczna towarzyszyła mi w analizach danych empirycznych i poszukiwaniu odpowiedzi na pytanie, jakie są dyskursywne reprezentacje sprawiedliwości i odpowiedzialności w narracjach osób z sektora pozarządowego zajmujących się edukacją globalną w Polsce.

\section{Rezultaty}

„Nie mam pojęcia zielonego, jak zdefiniować sprawiedliwość"

Sprawiedliwość pojawia się w analizowanym materiale w trzech aspektach: jako jeden z tematów podejmowanych przez edukację globalną (przede wszystkim zagadnienie Sprawiedliwego Handlu ${ }^{1}$ ), jako ważna wartość z nią związana („sprawiedliwość, równość i otwartość”; „Zrównoważoność, sprawiedliwość, równość, godność i wolność”, ,godność ludzka, sprawiedliwość, równość”); oraz jako cel edukacji globalnej. Moi rozmówcy i rozmówczynie mówili np., że „edukacja globalna jest jedną ze wspaniałych metod na zmniejszanie niesprawiedliwości na świecie” (W7) albo że jednym z jej celów jest „aktywizacja do podejmowania działań na rzecz lepszego, bardziej sprawiedliwego świata" (W6).

Mimo że sprawiedliwość wskazywana była jako jedna z podstawowych wartości edukacji globalnej, jej zdefiniowanie sprawiło respondentom/tkom spore kłopoty:

1 „Sprawiedliwy Handel to partnerstwo handlowe, oparte na dialogu, przejrzystości i szacunku, które dąży do większej równości w handlu międzynarodowym. Przyczynia się do zrównoważonego rozwoju przez oferowanie lepszych warunków handlowych oraz ochronę praw marginalizowanych producentów i pracowników najemnych, szczególnie w krajach Południa. Organizacje Sprawiedliwego Handlu (wspomagane przez konsumentów) są aktywnie zaangażowane we wspieranie producentów, podnoszenie świadomości i kampanie na rzecz zasad i praktyk konwencjonalnego handlu międzynarodowego" (definicja FINE - nieformalnej platformy skupiającej międzynarodowe organizacje działające na rzecz Sprawiedliwego Handlu). Za: http://www.sprawiedliwyhandel.pl (otwarty: 23.03.2017). 
„no, mętną mam tę sprawiedliwość, ale nie pokusiłbym się o definicję / nie pokusił się" (W7); „ja nie podejmuję się sformułowania definicji sprawiedliwości” (W10); „nie mam pojęcia zielonego, jak zdefiniować sprawiedliwość” (W9). Czasem osobom, z którymi rozmawiałam, znacznie łatwiej było określić, czym sprawiedliwość nie jest: „to nie jest to samo dla wszystkich, ani wszystkim według potrzeb, ani wszystkim według zasług, no nie" (W9). W tych przypadkach, w których jednak próbowano wyjaśnić pojęcie sprawiedliwości, najczęściej definiowano ją przez odwołanie do równości. Jedna osoba mówiła o sprawiedliwości jako równym dostępie do podstawowych dóbr, takich jak edukacja czy opieka medyczna, inna - o wyrównywaniu szans. Niektórzy odwoływali się do lektur (np. Ideals of justice Amartyi Sena) albo do wykładów na studiach, czyli do wiedzy eksperckiej, która miałaby legitymizować ten sposób rozumienia.

Co jest ciekawe i odróżnia polskie środowisko pozarządowe zajmujące się edukacją globalną od np. brytyjskiego, irlandzkiego czy kanadyjskiego, to całkowita niemal nieobecność kategorii „sprawiedliwość społeczna”. W zachodniej literaturze przedmiotu i praktyce edukacyjnej sprawiedliwość społeczna jest silnie powiązana $\mathrm{z}$ edukacją globalną $\mathrm{w}$ wymiarze celowościowym, treściowym i aksjologicznym (Bourn 2015; Davies 2006; Landorf, Nevin 2007; Oxfam 1997). W zebranym przeze mnie materiale natomiast pojawia się właściwie sporadycznie, przy czym jeden z moich rozmówców wprost stwierdził, że w jego organizacji „na razie” nie używają tego pojęcia. Inna osoba wspomniała, że to kwestia kontrowersyjna: „jest bardzo dużo osób, które są sceptycznie nastawione np. do zmian klimatu, czy do kwestii niesprawiedliwości społecznej. To przez nasze chyba historyczne obciążenie. Różne związane z tym, czy sprawami pracowniczymi, no to są tematy..." (W2).

Kolejny rozmówca odniósł się do tego zagadnienia szerzej: „Dlaczego w Polsce wtedy [pod koniec lat 9o. - MKH] nie używaliśmy pojęcia «sprawiedliwość społeczna»? Bo się z komunizmem kojarzy, jak najgorzej. [...] Teraz, właśnie wczoraj, odkryłem, że w konkursie o fundusze norweskie jest jako jeden z celów wprowadzenie sprawiedliwości społecznej, to poczułem, że to jest taka epokowa zmiana właśnie. Bo kiedyś, 10 lat temu, 15, to było nie do pomyślenia, bo to było jednoznaczne z jakimś, nie wiem, socjalizmem, tak?" (W7). Ten sam rozmówca określał sprawiedliwość społeczną jako „zachodni sposób myślenia”, odmienny od „polskiego”, mówił np. o zderzeniu i konfrontacji paradygmatów. Sprawiedliwość i sprawiedliwość społeczna były dyskursywnie konstruowane jako całkowicie odmienne, nieprzystające do siebie. Kategoria sprawiedliwości społecznej w jego ujęciu stała się też fundamentem wyróżniającym jedną z odmian edukacji globalnej: „nurt polityczny, taki związany właśnie ze sprawiedliwością społeczną w wymiarze globalnym". W tym kontekście mówienie o wartości sprawiedliwości społecznej (a nie o sprawiedliwości po prostu) jawi się jako swego rodzaju manifest, deklaracja przynależności do określonego środowiska - środowiska, które realizuje bardziej świadomą, zaangażowaną, krytyczną edukację globalną: „mówimy dużo o sprawiedliwości społecznej" (W1). 
Dokładniejsza analiza kategorii „sprawiedliwości” w wywiadach pokazuje, że funkcjonuje ona jak puste hasło, niewiele znaczący slogan, pojawiający się w wypowiedziach badanych najczęściej, jak wspomniałam, w kontekście „Sprawiedliwego Handlu” jako jednego z tematów edukacji globalnej. Sformułowanie „Sprawiedliwy Handel" skłania jednak do postawienia pytania o to, czy jest też handel niesprawiedliwy i w jaki sposób mówią o nim osoby, z którymi rozmawiałam. Analiza konkordancji kategorii „niesprawiedliwość” (choć ograniczona do pięciu wywiadów, w których ta kategoria się pojawia) pozwala zidentyfikować dominujący $\mathrm{w}$ wywiadach dyskurs niesprawiedliwości. Wiąże on niesprawiedliwość z globalnym systemem gospodarczym i relacjami międzypaństwowymi, z międzynarodowym handlem uprzywilejowującym jednych kosztem innych, z wyzyskiem ekonomicznym wynikającym z nierównych, nieuczciwych zasad gry: „nie możemy nie zajmować się niesprawiedliwościami w handlu międzynarodowym czy umowach wielostronnych” (W9); „byłaby zainteresowana zburzeniem tego systemu, który ja uważam za niesprawiedliwy” (W10); „albo ten człowiek akceptuje to, jak ten handel międzynarodowy wygląda, czyli akceptuje niesprawiedliwość, tak przynajmniej ja to odczuwam i parę osób też, że jest to niesprawiedliwe" (W7). To jest dyskurs, który jest elementem narracji charakterystycznej dla krytycznej edukacji globalnej. Koncentruje ona uwagę przede wszystkim na niesprawiedliwości i nierównościach we współczesnym świecie, odrzuca założenia o niedorozwoju czy braku edukacji jako przyczynie problemów danego kraju na rzecz przekonania, że to złożone struktury, systemy oraz relacje międzynarodowe i międzyludzkie tworzą i podtrzymują wyzysk (Andreotti 2011). Należy jednak dodać, że w analizowanych wywiadach niesprawiedliwość jest lokowana poza jednostką, gdzieś daleko, w jakimś enigmatycznym systemie. Jednostka nie partycypuje w jej podtrzymywaniu, może natomiast jej przeciwdziałać czy się jej przeciwstawiać. Jest więc częścią rozwiązania, ale nie częścią problemu. To z kolei wydaje się niezgodne z narracją krytycznej edukacji globalnej, w której podkreśla się różnorakie formy i przejawy uwikłania podmiotu w struktury i instytucje kreujące niesprawiedliwość.

Wyjątkiem są dwa wywiady, w których wprost - choć nie w kontekście niesprawiedliwości - rozmówcy mówią o takim uwikłaniu: o wyzyskiwaniu krajów globalnego Południa przez nas samych i o jednostronnym, eurocentrycznym przekazie edukacyjnym dotyczącym odkryć geograficznych i skutków konkwisty: „żebyśmy wiedzieli, że rzeczy, które nosimy... nie do końca to jest tak, że jeżeli kupujemy w sklepie w Polsce, to one są zrobione w Polsce, że to jest o wiele dłuższy proces, że nasza komórka, nasz komputer, to też jest szereg różnych procesów... i też okazuje się, że na samym końcu są kraje globalnego Południa, gdzieś w tych łańcuchach uwikłane i tak naprawdę... to je w jakiś sposób - może to jest mocne słowo - wyzyskujemy” (W1); „jest dla mnie ważne, żeby edukacja globalna nie utrwalała fałszywych przeświadczeń. Że na przykład fakt, że Kolumb dotarł do Ameryki, to ją odkrył i coś dobrego z tego wynikło. No, bo wynikło dla jednych coś dobrego, a dla innych wynikło coś strasznego" ( $\left.\mathrm{W}_{7}\right)$. 
„Zachęcać ludzi do współodpowiedzialności za świat”...

Odpowiedzialność pojawia się w wywiadach o połowę rzadziej niż sprawiedliwość. W jednym wywiadzie nie występuje wcale, w dwóch - wyłącznie jako część nazwy własnej. Zatem analiza objęła dziewięć z 12 przeprowadzonych wywiadów.

Podobnie jak analizowana wcześniej kategoria sprawiedliwości, także odpowiedzialność ujmowana jest jako:

- wartość: „poczucie współodpowiedzialności jest kluczowe” (W4); „ponoszenie odpowiedzialności za to, co się robi [...] myślenie o tym, jakie konsekwencje mogą być" (W2);

- treść, m.in. takie tematy, jak: odpowiedzialna konsumpcja i turystyka, kampania „Kupuj odpowiedzialnie”;

- oraz cel edukacji globalnej. W tym ostatnim aspekcie odpowiedzialność konstruowana jest jako pożądana cecha globalnego obywatela, możliwa do osiągnięcia dzięki zabiegom edukacyjnym: „wychowujemy do pozytywnych rzeczy, do odpowiedzialności za to, co wokół nas po prostu” (W5); „uczymy odpowiedzialności za każdy wybór, głównie konsumencki” (W4). Zdaniem wielu moich rozmówców i rozmówczyń w edukacji globalnej chodzi o „pokazywanie i uwrażliwianie uczniów, że jesteśmy odpowiedzialni za to, co robimy, i to ma wpływ na to, co się dzieje w krajach globalnego Południa" (W6); o ukształtowanie „takiego poczucia, że jestem tego częścią, i że ja jestem jakoś tam odpowiedzialny za to, co się tam dzieje" (W10). Odpowiedzialność według badanych jest lub powinna być zakorzeniona w poczuciu wspólnoty (lokalnej, narodowej i globalnej), do której należy jednostka.

Dyskursywnie konstruowana odpowiedzialność jest waloryzowana pozytywnie, kojarzy się z czymś dobrym. Nie jest to pełna analiza prozodii semantycznej ${ }^{2}$ tego pojęcia, ale taki wniosek nasuwa się przy bliższym oglądzie. Odpowiedzialność (odpowiedzialny/a) zastępowana jest takimi słowami, jak: mądre (podróżowanie); dobre (wybory); świadome (decyzje, wybory); pozytywne (rzeczy); przemyślane (wybory, decyzje).

Dla porządku należy odnotować, że pojawiają się w wywiadach także odniesienia do odpowiedzialności jako czegoś negatywnego czy niepożądanego („przerzucanie odpowiedzialności”, „bronić się przed odpowiedzialnością”), ale wyłącznie w kontekście działań agend rządowych czy ministerstw, co tworzy pewną opozycję: świat pozarządowy, który traktuje odpowiedzialność jako pożądaną właściwość obywatela, czyli członka wspólnoty, versus świat administracji rządowej, który umywa ręce, zachowuje się niedojrzale, broniąc się przed przyjęciem na siebie odpowiedzialności.

2 Prozodia semantyczna to „powtarzająca się konsekwentnie aura znaczeniowa, którą dane słowo zostaje przepojone przez swoje kolokacje” (Louw, za: Kamasa 2014). 
Dokładniejsza analiza (wraz z analizą konkordancji) wskazuje na to, że odpowiedzialność związana jest $\mathrm{z}$ wolnym wyborem, $\mathrm{z}$ autonomiczną decyzją jednostki, z poczuciem i realną możliwością wpływu na sytuację wokół: „bo jak mam poczucie odpowiedzialności, że to też ode mnie zależy i ja jestem za to odpowiedzialny, to chcę albo nie chcę wpływać na kształt tych poszczególnych spraw” (W10); „tą główną postawą jest właśnie odpowiedzialność i to, żeby się zaangażować w jakieś działania i po prostu podejmować dobre wybory na co dzień, które nie będą szkodzić ani tutaj lokalnie, ani globalnie” (W5); „jesteśmy odpowiedzialni za to, co robimy, i to ma wpływ na to, co się dzieje w krajach globalnego Południa" (W6).

Zgodnie ze słownikową definicją odpowiedzialność oznacza:

4) obowiązek moralny lub prawny odpowiadania za swoje (lub czyjeś) czyny; ponoszenie konsekwencji za działanie lub zaniechanie;

5) przyjęcie na siebie obowiązku zadbania o kogoś lub coś („odpowiedzialność” 2017).

W wywiadach w zasadzie nie pojawia się powiązanie odpowiedzialności z winą czy ciężarem. Są odniesienia do konsekwencji (lokalnych i globalnych, do ludzi i do środowiska naturalnego), ale dotykają one przede wszystkim Innych, mieszkańców globalnego Południa, a nie mnie: „w jaki sposób my wpływamy swoją codziennością, swoimi codziennymi nawykami na to, jak wygląda sytuacja gdzieś tam, po drugiej stronie świata” (W6); „często my tu, w Polsce, możemy zrobić więcej dla tych ludzi niż oni sami dla siebie tam na miejscu. To znaczy my, swoimi decyzjami w bardzo duży sposób możemy zaciążyć na ich życiu” (W4).

Znacznie wyraźniejsze, dominujące, jest dyskursywne konstruowanie odpowiedzialności w kategoriach (moralnego) obowiązku czy powinności zadbania o świat - lokalnie i globalnie. Ta powinność z kolei wyrasta ze wspomnianego przekonania, że jednostka ma wpływ na to, co się dzieje i że jej indywidualne działania mogą przynieść zmianę w świecie: „jesteśmy odpowiedzialni za to, co robimy i to ma wpływ na to, co się dzieje w krajach globalnego Południa" (W6); „żebyśmy mieli tę świadomość właśnie w takich zwykłych codziennych rzeczach, że kupując coś mamy wpływ na coś” (W3); „pokazywanie, że moje wybory faktycznie mają wpływ na innego człowieka, gdzieś tam, w innym zakątku świata” (W5). Dyskurs odpowiedzialności konstruuje tożsamość „nas”, ludzi żyjących w krajach globalnej Północy i będących w uprzywilejowanej pozycji, w kategoriach podmiotowości, sprawstwa, czynu, działania, możliwości wpływania na świat; usuwa zaś z pola widzenia podmiotowość i sprawstwo mieszkańców i mieszkanek globalnego Południa. Tworzy to charakterystyczną opozycję: „my”, od których coś zależy i którzy działają, oraz „oni/one”, którzy są obiektem naszych oddziaływań czy wpływu.

Te odpowiedzialne wybory, decyzje i działania, na które mieszkańcy i mieszkanki uprzywilejowanych części świata mogą się zdecydować, najczęściej odnoszą się do sfery konsumpcji - rozmówcy i rozmówczynie mówią o odpowiedzialnej konsumpcji, odpowiedzialnej turystyce, kupowaniu produktów pochodzących ze 
Sprawiedliwego Handlu: „Że kupno czekolady to jest bezpośrednia jakby walka o prawa człowieka, tego, kto te ziarna kakaowca zbiera” (W5); „Nasze codzienne nawyki konsumenckie mają wpływ na to, co się dzieje np. w kraju producentów danych dóbr i danych usług, z których na co dzień korzystamy, często nie zdając sobie sprawy” (W6); „Bo w ten sposób właśnie poprzez zakupy, nawet zakup wycieczki w biurze podróży, nie tylko zakup bananów czy ananasów, wpływamy właśnie na sytuację krajów globalnego Południa" (W4). Popularność tego ujęcia może budzić pewne niepokoje, jako że promuje ono raczej globalnego odpowiedzialnego konsumenta niż obywatela, działacza czy aktywistę. Podsuwa rozwiązania indywidualistyczne, które, jak podkreślają krytycy (Andreotti 2011; Bryan 2013; Swanson, Pashby 2016; Tarc 2011), nie podważają istniejącego porządku społeczno-politycznego, podtrzymującego te nierówności. I chociaż większość moich rozmówców i rozmówczyń otwarcie krytykowała filantropijne czy charytatywne podejście do problemów globalnych (jako nieskuteczne, paternalistyczne i rozgrzeszające), to jednak nie udało im się (z pewnymi wyjątkami) wyjść poza dominujący dyskurs pomocowy i konsumencki, poza paradygmat dawcy-biorcy pomocy.

Jeśli przyjrzymy się dokładniej, używając narzędzi heurystycznych, wywiedzionych z krytycznej edukacji globalnej, możemy zauważyć, że to nie jest krytycznie rozumiana odpowiedzialność. Jak podkreśla Andreotti (2006, 2011), jedną z kluczowych charakterystyk krytycznego globalnego obywatela jest odpowiedzialność WOBEC Innego (a nie ZA Innego). Odpowiedzialność WOBEC Innego zakorzeniona jest $\mathrm{w}$ uznaniu naszego historycznego, społecznego i kulturowego uwikłania w niesprawiedliwość, opresję i krzywdy wyrządzone Innemu. Natomiast odpowiedzialność ZA Innego wiąże się z zadbaniem o kogoś, kto jest w gorszej, mniej uprzywilejowanej pozycji, kto jest słabszy bądź niesamodzielny. W wywiadach zdecydowanie dominuje odpowiedzialność ZA Innego: „za los ludzi żyjących w bardzo odległych miejscach”, „za to, co się tam dzieje”, „za to, co wokół nas” etc. Niemal nieobecne jest uznanie współwiny czy przyznanie, że jesteśmy częścią problemu, a nie tylko jego rozwiązaniem. Jesteśmy odpowiedzialni ZA Innego „od teraz", a nie za przeszłość, która jest w zasadzie znaturalizowana. Świadomość historyczności teraźniejszości pojawia się sporadycznie.

Na tym tle wyróżniają się trzy osoby, które w rozmowie nie mówiły o odpowiedzialności, w ogóle nie używały tego słowa. W ich wypowiedziach pojawiają się, cytowane wcześniej, wątki historycznych i społeczno-kulturowych uwarunkowań teraźniejszości. Wyraźnie wybrzmiewa także współwina (europejski imperializm, podboje kolonialne) i konieczność gruntownej rewizji sposobu myślenia w kierunku dostrzegania i uwzględniania wielości perspektyw: „można zobaczyć ten problem całościowo, jaka jest w tym nasza rola, jaka jest rola krajów bogatych, krajów globalnego Południa, co się tam dzieje, co robią władze, spojrzeć na to całościowo. I na tym nam najbardziej zależy” (W11); „[Jeśli - MKH] jestem otwarty maksymalnie na inne punkty widzenia, na odkrywanie tego, że z całkiem różnych powodów historyczno-kulturowych ludzie o tej samej rzeczy myślą całkiem inaczej 
i o wspólnych naszych rzeczach, co nas łączy, że jest całkiem inna perspektywa. I nigdy nie będzie się w pełni miało wszystkich perspektyw światowych, bo to jest fizycznie niemożliwe. [...] Ale jeśli [człowiek - MKH] rozumie, że większość ludzi na świecie o jakiejś tam sprawie myśli inaczej niż ja, to przyjmuje to jako uzasadniony i godny szacunku pogląd" (W7).

W analizowanych wypowiedziach brakuje jednak alternatywnej, dyskursywnie skonstruowanej odpowiedzialności (być może brakuje języka?). Proponowana przez Andreotti odpowiedzialność wobec Innego mogłaby być w tym kontekście pomocna.

\section{Zakończenie}

Z perspektywy krytycznej edukacji globalnej różni autorzy (np. Andreotti 2011; Bryan, Bracken 2011; Jefferess 2008; Pashby 2014) krytykują dominujący dyskurs globalnego obywatelstwa, pomocy czy odpowiedzialności za to, że w gruncie rzeczy maskuje on i wzmacnia nierówne relacje władzy, proponując rozwiązania nieskuteczne bądź pozorne, nieodnoszące się do przyczyn globalnych problemów. Krytyka dotyczy także definiowania globalnego obywatela jako podmiotu mającego możliwości i zdolności do działania na rzecz lepszego świata DLA Innych, a nie Z Innymi. Inny jest w dominującym dyskursie konstruowany jako obiekt dobroczynności, empatii bądź współczucia (Jefferess 2008). Jego uprzedmiotowienie podkreśla naszą podmiotowość i sprawstwo. Zaprezentowane $\mathrm{w}$ artykule analizy wskazują na podobne procesy. Dyskursywnie konstruowana odpowiedzialność kojarzona jest z nami, mieszkankami i mieszkańcami globalnej Północy, znajdującymi się w uprzywilejowanej pozycji, mającymi możliwość wyboru właściwych zachowań, podejmowania odpowiednich decyzji i działań. Jest to w dominującym ujęciu odpowiedzialność ZA, a nie WOBEC Innego. Podobnie, dominujące dyskursywne reprezentacje sprawiedliwości i - zwłaszcza - niesprawiedliwości, choć w pewnej mierze krytyczne, też lokują nas na pozycji nieuwikłanych, czystych moralnie podmiotów działania, superbohaterów, od których zależą losy globalnego Południa. Pomija się przy tym złożone historyczne, społeczne i kulturowe procesy warunkujące teraźniejszość. Stawia to pod znakiem zapytania ideały partnerstwa, równości i współpracy, bliskie edukacji globalnej oraz moim rozmówcom i rozmówczyniom.

W artykule zaprezentowałam niewielki wycinek badań, otwierający pole do dalszych poszukiwań, w których warto byłoby przyjrzeć się np. jak analizowane kategorie funkcjonują w materiałach edukacyjnych publikowanych przez organizacje pozarządowe oraz w szkolnej praktyce edukacyjnej. Taka rekonstrukcja może stanowić punkt wyjścia do realizacji mniej paternalistycznej, bardziej krytycznej edukacji globalnej: „żeby to nie było w ten sposób, [...] że [to są - MKH] biedni, absolutnie bezwolni ludzie, którym my, dobrzy Europejczycy, pomożemy" (W1). 


\section{Bibliografia}

Andreotti V. (2006). Soft versus critical global citizenship education. „Policy \& Practice: A Development Education Review", vol. 3, s. 40-51.

Andreotti V. (2011). Actionable Postcolonial Theory in Education. New York and London: Palgrave Macmillan.

Andreotti V. (2014). Critical literacy: theories and practices in development education. „Policy \& Practice: A Development Education Review”, vol. 14, s. 12-32.

Andreotti V., De Souza L. M. T. (2014). Introduction: (Towards) global citizenship education «otherwise». W: Andreotti, V., De Souza, L. M. T. (red.). Postcolonial perspectives on global citizenship education. Abingdon-New York: Routledge.

Bourn D. (2015). The Theory and Practice of Development Education: A Pedagogy for Global Social Justice. Abingdon: Routledge.

Bryan A., Bracken M. (2011). Learning to read the world? Teaching and learning about global citizenship and international development in post-primary schools. Dublin: Irish Aid and Identikit, dostępny na: http://www.developmenteducation. ie/resources/development-education/learning-to-read-the-world.html (otwarty: 20.03.2017).

Bryan A. (2013). „The Impulse to Help”: (Post) humanitarianism in an era of the "new" development advocacy. „International Journal of Development Education and Global Learning", vol. 5 (2), s. 5-29.

Davies L. (2006). Global citizenship: Abstraction or framework for action? „Educational Review”, vol. 58 (1), s. 5-25.

GLEN. (2009). Global Education Guide, dostępny na: http://glen-europe.org/wp-content/uploads/2010/11/GLEN-GE-Guide-2009.pdf (otwarty: 22.03.2017).

Jefferess D. (2008). Global citizenship and the cultural politics of benevolence. "Critical Literacy: Theories and Practices”, vol. 2 (1), s. 27-36.

Kamasa V. (2014). Techniki językoznawstwa korpusowego wykorzystywane w krytycznej analizie dyskursu. Przegląd. „Przegląd Socjologii Jakościowej”, nr 2, s. 100-117.

Landorf H., Nevin A. (2007). Inclusive global education: implications for social justice. „Journal of Educational Administration", vol. 45 (6), s. 711-723.

Mayring Ph. (2000). Qualitative Content Analysis. „Forum Qualitative Sozialforschung/Forum: Qualitative Social Research", vol. 1 (2), art. 20, dostępny na: http://www.qualitative-research.net/index.php/fqs/article/view/1089/2385 (otwarty: 07.01.2017).

Odpowiedzialność. (2017). W: Słownik języka polskiego, dostępny na: http://sjp.pwn. pl (otwarty: 23.03.2017).

Odpowiedzialność globalna i edukacja globalna: wymiary teorii i praktyki (2012). Ciążela H. (red). Warszawa: Wydawnictwo Akademii Pedagogiki Specjalnej. Ostrowicka H. (2014). Kategoria dyskursu w języku i w badaniach edukacyjnych - w poszukiwaniu osobliwości pedagogicznie zorientowanej analizy dyskursu. „Forum Oświatowe”, vol. 52 (2), s. 47-68. 
Oxfam. (1997). A curriculum for global citizenship. Oxford: Oxfam.

Pashby K. (2014). Questions for global citizenship education in the context of the "new imperialism": For whom, by whom? W: Andreotti V., De Souza L. M. T. (red.). Postcolonial perspectives on global citizenship education. Abingdon-New York: Routledge.

Popow M. (2015). Globalna Pólnoc i Globalne Południe w dyskursie edukacyjnym. Krytyczna analiza treści podręczników szkolnych. „Studia Edukacyjne”, nr 35, s. 251-273.

Swanson D. M., Pashby K. (2016). Towards a c r i t i c a l global citizenship? A comparative analysis of GC education discourses in Scotland and Alberta. "Journal of Research in Curriculum \& Introduction", vol. 20 (3), s. 184-195.

UNESCO. (2014). Global citizenship education: Preparing learners for the challenges of the 21st century. Paris: UNESCO, dostępny na: http://en.unesco.org/gced (otwarty: 17.11.2016).

Wodak R., Fairclough N. (1997). Critical Discourse Analysis. W: van Dijk T. (red.), Discourse as Social Interaction: Discourse Studies - a Multidisciplinary Introduction, vol. 2, London: SAGE Publications Ltd.

\title{
JUSTICE AND RESPONSIBILITY IN GLOBAL EDUCATION (IN THE NARRATIVES OF NON-GOVERNMENTAL ORGANIZATIONS' EMPLOYEES)
}

\begin{abstract}
The aim of the article is to analyse the representations of justice and responsibility in the narratives of non-governmental organisations' employees working in the area of global education in Poland. The categories of justice and responsibility are treated as socio-cultural constructs that both constitute social practice and are constituted by it. The study uses qualitative content analysis of 12 individual in-depth interviews, complemented by a concordance analysis. The research is informed by critical global education and a discursive approach. The analysis has revealed dominant discursive representations of justice and responsibility as well as their potential results. The data have shown that responsibility is linked to privileged people in the global North, who have the freedom of choosing the right behaviour and making the right decisions. It is a responsibility for the Other, not towards the Other, who is positioned as an object of one's activity. The dominant representations of justice and injustice also create people from the global North as subjects not complicit in global harm, from whom the future of global South depends. The alternative discourse is much weaker.
\end{abstract}

Keywords: global education, discourse, non-governmental organisations, justice, responsibility, qualitative methods.

Magdalena Kuleta-Hulboj - z wykształcenia socjolożka i pedagożka, doktor nauk humanistycznych w zakresie pedagogiki, adiunkt w Katedrze Pedagogiki Społecznej i Pedagogiki 
Specjalnej na Wydziale Pedagogicznym Uniwersytetu Warszawskiego. Zainteresowania naukowe: edukacja globalna, międzykulturowa, metodologia badań jakościowych, krytyczna analiza dyskursu. Autorka książki Pamięć-edukacja-dialog. Studium przypadku polsko-izraelskiej wymiany młodzieży (Toruń 2009) i współredaktorka książek o edukacji globalnej: Teoretyczne i praktyczne konteksty edukacji globalnej (z Z. Babickim, Warszawa 2016) i Edukacja globalna. Polskie konteksty i inspiracje (z M. Gontarską, Wrocław 2015). Adres e-mailowy:m.kuleta-hulboj@uw.edu.pl. 